\title{
FGF18 Gene
}

National Cancer Institute

\section{Source}

National Cancer Institute. FGF18 Gene. NCI Thesaurus. Code C153047.

This gene is involved in bone development and cell proliferation in the liver and small intestine. 